\section{The Relationship Between Self Control With Intensity of Playing Online Games on The School Children}

Novita Febriyanti Rahayu Putri; Susanti Prasetyaningrum

Fakultas Psikologi, Universitas Muhammadiyah Malang

e-mail: novitafrputri@gmail.com
Journal PSIKODIMENSIA

Volume 17, No. 2, Juli - Desember 2018

ISSN cetak : 1411-6073

ISSN online : 2579-6321

DOI 10.24167/psidim.v17i2.1636

\begin{abstract}
This research aims to know the relationship between self control with intensity of playing online games on the school children. The methods on this research is quantitative correlation, with the instrument is self control scale and intensity of playing online games scale. Quantity of subject is about 140 students of SDN Branta Paseser 1 Pamekasan who selected based on proportionate stratified random sampling techniques. The result shows that there is a relationship between self control with intensity of playing online games on the school children This means if the higher self control owned students, so the lower level intensity of playing online games. Beside that, the contribution of effective self control to the intensity of playing online games on the school children is about 64.6\%.

Keywords: self control, intensity of playing online games, school students.
\end{abstract}

\section{PENDAHULUAN}

Masa kanak-kanak merupakan masa yang penting dalam perjalanan hidup individu. Pada masa ini, anakanak memiliki minat yang besar terhadap suatu permainan sehingga usia ini dapat disebut sebagai usia bermain. Bermain merupakan unsur yang penting dalam kehidupan anak baik untuk perkembangan fisik, emosi, mental, intelektual maupun sosialnya (Soetjiningsih, 2012).Hurlock (2008) mengatakan bahwa permain yang paling diminati anak-anak pada usia sekolah merupakan permainan yang bersifat persaingan. Permainan yang diminati anak-anak saat ini tidak hanya permainan yang bersifat tradisional saja, melainkan permainan yang bersifat modernpun seakan menjadi pilihan utama dan telah menjamur pada kalangan anak-anak saat ini, seperti adanya gameonline.

Seiring dengan perkembangan zaman yang semakin maju membuat perkembangan teknologi juga semakin pesat. Salah satu bukti nyata perkembangan teknologi adalah dengan adanya internet. Internet dapat digunakan oleh siapapun dan kapanpun tidak terkecuali anak-anak. Internet dapat digunakan untuk keperluan yang beragam seperti browsing, chatting, menonton video di youtube, maupun untuk bermain game. Berdasarkan hasil survei yang telah dilakukan oleh Asosiasi Penyelenggara Jasa Internet Indonesia (APJII) diketahui bahwa jumlah pengguna internet di Indonesia setiap tahunnya mengalami peningkatan. APJII melaporkan bahwa pada tahun 2012 jumlah pengguna internet di Indonesia mencapai $24,23 \%$ dari jumlah penduduk Indonesia. Sedangkan pada tahun 2014 jumlah pengguna internet meningkat menjadi $34,9 \%$ atau sekitar 88,1 juta pengguna di Indonesia. Pada tahun 2015 jumlah pengguna internet kembali meningkat menjadi $50 \%$ dari total penduduk Indonesia. Selanjutnya pada tahun 2016 APJII mengklasifikan 
kategori pengguna internet mulai usia dari anak-anak hingga orang dewasa. Hasilnya, generasi produktif dengan umur 25-29 tahun menempati peringkat teratas dengan pengguna internet sebanyak 24 juta, kemudian usia 30-34 tahun mencapai 23,3 juta. Lalu disusul secara berurutan diikuti oleh 20-24 tahun (22,3 juta), 40-44 tahun (16,9 juta), 15-19 tahun (12,5 juta), 45-49 tahun (7,2 juta), 50 tahun keatas $(1,5$ juta) dan 10-14 tahun dengan 768 ribu.

Internet memberikan berbagai kemudahan bagi setiap individu yang menggunakannya. Fenomena adanya internet, setiap individu dapat mengakses berbagai macam sarana, seperti sebagai sarana promosi, sarana bekomunikasi, serta dapat dijadikan sebagai media hiburan (menonton video, bermain game, maupun bergabung dengan komunitas tertentu). Namun keberadaan internet yang dapat diakses oleh siapapun dan kapanpun seolah

menjadi bumerang bagi setiap individu yang mengaksesnya karena selain dapat memberikan pengaruh yang positif, keberadaan internet juga dapat memberikan pengaruh yang negatif kepada para pengaksesnya terutama anak-anak. Pertumbuhan internet, lebih banyak orang memiliki akses ke gameonline (Teng, Li, dan Liu, 2014). Gameonline adalah bentuk hiburan yang populer yang dapat mempengaruhi kualitas hidup pemain (Shen \& Williams dalam Teng 2014).

Gameonline mempunyai perbedaan yang sangat besar dengan game lainnya, yaitu pemain gametidak hanya dapat bermain dengan orang yang berada di sebelahnya namun juga dapat bermain dengan beberapa pemain lain di lokasi lain, bahkan hingga pemain di belahan bumi lain (Young, 2009). Anakanak dianggap lebih sering dan lebih rentan terhadap penggunaan permainan gameonline daripada orang dewasa
(Griffiths \& Wooddalam Lemmens, 2009)

Jumlah pemain gameonline di Indonesia terus meningkat setiap tahunnya. Hasil survei menunjukkan bahwa jumlah pemain gameonline di Indonesia meningkat antara 5\%-10\% setiap tahunnya dimana pada tahun 2014 terdapat 25 juta orang indonesia telah bermain gameonline (Tribunnews.com, 2018). Artinya, terdapat perkembangan yang pesat dan signifikan mengenai jumlah pemain game online di Indonesia setiap tahunnya. Hal tersebut membuat Indonesia menduduki peringkat keempat sebagai negara dengan jumlah pemain gameonline terbanyak di dunia. Menurut SuperData, persentase konsumen gamemobile di Indonesia hampir 50\% lebih tinggi dibandingkan India. Dilihat dari pertumbuhannya, saat ini konsumen gamemobile Indonesia memiliki karakteristik yang hampir menyerupai wilayah Jepang, Korea Selatan, dan juga Cina (idtechinasia.com).

Tingginya intensitas bermain gameonline di Indonesia membuat para pemainnya menjadi pecandu gameonline dan mengabaikan serta melupakan kegiatannya sehari-hari guna dapat bermain game secara terus menerus (Nuhan, 2016).Dampak yang akan sangat terlihat adalah ketagihan dalam bermain gameonline seperti lupa waktu, lupa diri, kurangnya sosialisasi individu terhadap lingkungannya, lebih mudah emosi, mudah dipengaruhi oleh perasaan, mempengaruhi pola pikir, lupa tanggung jawab pribadi, serta melupakan kehidupan sebenarnya (Nuhan, 2016; Young 2009). Hal ini akan memberikan dampak buruk bagi individu terutama anak-anak baik terhadap dirinya sendiri, kesehatannya, emosinya, psikisnya maupun lingkungannya. Dampak bermain game online secara psikologi bagi anak-anak antara lain adalah anak dapat menarik diri dari lingkungan, mudah kehilangan 
kendali, serta tidak peduli dengan kegiatan lain disekitarnya.

Sifatgame onlineyang dapat memberikan efek ketagihan bagi anakanak yang membuat mereka tidak dapat mengontrol keinginan untuk bermainsehingga menyebabkan tingginya intensitas bermain game online yang dirasakan oleh anak-anak. Tentunya hal ini akan berdampak dan berakibat buruk bagi mereka. Anakanakakan malas untuk belajar, kurang dapat berkonsentrasi karena selalu ingin bermain gameonline, melupakan pekerjaan rumah (PR), serta tidur tidak pada waktunya. Ismail danZawahreh(2017) mengatakan bahwa kecanduan internet dan gameonline menyebabkan hilangnya kontrol, penarikan, pelemahan fungsi, dan ketidakmampuan pengambilan keputusan, sebuah pengalaman, kecemasan, gairah dan kegembiraan psikomotor dan agresi.

Fenomena yang saat ini terjadi adalah tingginya tingkat intensitas anak dalam bermain gameonline. Hal ini dipertegas dengan hasil survei yang dilakukan oleh Pertiwi (dalam rappler.com) yang mengatakan bahwa tingginya akses internet yang dilakukan oleh anak-anak digunakan untuk bermain game online, menonton video di youtube, serta meningkatnya akses pada konten negatif. Kemudian berdasarkan hasil survei yang telah peneliti lakukan pada 10 anak dengan menggunakan metode wawancara, diketahui bahwa anak-anak yang bermain game online mengakses game tersebut melalui gadget milik orang tua, maupun datang ke warnet. Bahkan terdapat 3 orang anak yang telah memiliki gadgetpribadi. Karena mudahnya anak dalam mengakses game online tersebut menyebabkan tingginya tingkat intensitas anak dalam bermain game online. Anak-anak yang bermain game online memiliki keluhan-keluhan terhadap kondisi kesehatannya.

Diketahui pula bahwa anak-anak yang sering bermain gameonline telah mengalami penurunan berat badan, sering merasakan nyeri pada jari-jari tangan, mata merah, bahkan terdapat anak yang telah menggunakan kacamata. Berdasarkan hasil wawancara, diketahui bahwa anak yang memiliki intensitas yang tinggi dalam bermain game online memiliki ciri-ciri seperti, kurang fokus saat menerima pelajaran di sekolah, dan sulit berkonentrasi karena ingin bermain gameonline. Salah satu anak menyatakan bahwa ketika kalah, ia merasakan stres dan harus terus bermain hingga ia menang dan menaikkan level dalam gameonline tersebut. Dampak lain dari gameonline tersebut adalah kecenderungan anak memiliki sikap egois, bersikap seenaknya, keras kepala, bahkan menutup diri dari dunia luar sehingga anak jarang berinteraksi dengan orang-orang disekitarnya.

Terdapat faktor internal dan eksternal yang menyebabkan individu memiliki minat yang tinggi hingga merasakan kecanduan terhadap gameonline (Masya dan Candra 2016). Faktor internal tersebut adalah keinginan yang kuat dari diri individu untuk memperoleh nilai yang tinggi dalam gameonline, rasa bosan yang dirasakan individu ketika berada di rumah atau di sekolah, ketidakmampuan individu dalam mengatur prioritas untuk mengerjakan aktivitas penting lainnya, kurangnya selfcontrol dalam diri individu sehingga kurang mampu mengantisipasi dampak negatif yang timbul dari bermain gameonline secara berlebihan.

Faktor eksternal adalah pengaruh dari lingkungan, karena melihat temantemannya yang lain banyak yang bermain gameonline, kurang memiliki hubungan sosial yang baik, sehingga 
individu memilih alternatif bermain game sebagai aktivitas yang menyenangkan, kurangnya perhatian keluarga maupun orang tua terhadap anaknya, dan harapan orang tua yang melambung terhadap anaknya untuk mengikuti berbagai kegiatan seperti kursus dan les, sehingga kebutuhan primer anak seperti kebersamaan, bermain dengan keluarga menjadi terlupakan.

Masya dan Candra(2016) mengatakan bahwa tingginya tingkat bermaingameonline dapat terjadi karena kurangnya selfcontrol dalam diri individu sehingga kurang mampu mengantisipasi dampak negatif yang timbul dari bermain gameonline secara berlebihan.Artinya, apabila individu memilikiselfcontrol yang baik maka ia mampu mengelola dirinya serta mengontrol dirinya ketika bermain gameonline dan tidak bermain secara berlebihan. Jika dilihat melalui selfcontrol, individu yang reaktif dan terus reaktif (terbawa hanyut ke dalam situasi yang sulit) merupakan individu yang memiliki selfcontrol yang rendah. Sedangkan individu yang memiliki kemampuan mengendalikan diri(self control) yang tinggi akan cenderung proaktif atau memiliki kesadaran untuk memilih hal yang positif (Zulkarnain, 2002).

Perkembangan kemampuan kontrol diri individu dipengaruhi oleh faktor perkembangan fisiologis, pengenalan dan minat sosial, serta kematangan dan faktor belajar lingkungan (Hurlock, dalam Ursia 2013). Santrock (2012) mengatakan bahwa masa anak-anak pertengahan dan akhir merupakan masa meningkatnya kapasitas bagi regulasi diri yang dicirikan dengan usaha mengatur dan mengelola diri, perilaku, emosi dan pikiran yang menghasilkan kompetensi sosial dan pencapaian. Selanjutnya, Meggit (2013) mengatakan bahwa anak usia 8-9 tahun mulai mengembangkan nilai-nilai individual dan batasan moral yang pasti, yaitu mampu membedakan yang benar dan salah serta perbuatan baik dan buruk. Artinya pada masa kanak-kanak pertengan dan akhir yakni usia 8-9 tahun harusnya anak-anak telah memiliki kontrol diri yang terbentuk karena perkembangannya.

Fenomena tingginya tingkat intensitas bermain gameonlinedapat dirasakan oleh siapapun, terutama pada kalangan siswa usia sekolah. Menurut Lemmens (2009), anak usia sekolah lebih sering dan lebih rentan terhadap penggunaan permainan gameonline dari pada orang dewasa. Anak akan tertarik untuk bermain game online karena rasa penasaran terhadap persaingan dalam game tersebut yang membuat anak tertantang. Hurlock (2008) mengatakan bahwa permainan yang paling menarik bagi anak usia sekolah adalah permainan yang bersifat persaingan.Selain itu, tingginya tingkat intensitas bermain game online pada kalangan siswa usia sekolah juga dapat terjadi karena akses padagame tersebut caranya cukup mudah yaitu hanya membutuhkan smartphone dan koneksi internet atau cukup dating ke warung internet (warnet) dengan mambawa uang tiga ribu rupiah. Berdasarkan survei yang telah peneliti lakukan pada 10 orang anak, menunjukkan bahwa pemain game tersebut terdiri dari siswa Sekolah Dasar (SD) yang berusia 9 hingga 12 tahun.

Mereka memainkan game tersebut saat pulang sekolah, ketika berkumpul bersama teman-teman seusianya, bahkan rela untuk pulang sore hari hingga malam hari demi menyelesaikan dan menaikkan level permainan tersebut. Mereka mengatakan bahwa keinginan untuk mengalahkan teman dan menaikkan levelgame tersebut membuat mereka ingin terus bermain. Hal ini menunjukkan bahwa mereka memiliki selfcontrol yang rendah dimana mereka 
tidak mampu mengelola diri dengan baik serta tidak mampu mengontrol keinginan dan diri mereka ketika bermain gameonline tersebut.

Idealnya, anak usia sekolah dapat membatasi diri ketika bermain gameonline serta mendapat pengawasan yang baik dari orang tua ketika bermain sehingga dapat mengontrol frekuensi dan durasi bermain mereka karena mereka memiliki tugas utama yaitu belajar. Pada masa ini, Santrock (2012) mengatakan bahwa masa anak-anak pertengahan dan akhir merupakan masa meningkatnya kapasitas bagi regulasi diri yang dicirikan dengan usaha mengelola diri, perilaku, emosi dan pikiran yang menghasilkan kompetensi social dan pencapaian. Bermain gameonline dapat dilakukan apabila telah jenuh dalam belajar, namun dalam batas yang wajar. Hal tersebut dapat menunjukkan bahwa individu tersebut memiliki selfcontrol yang tinggi. Individu yang memiliki selfcontrol dapat membatasi perhatiannya pada hal-hal tertentu maupun orang lain, karena dengan adanya pengendalian diri, individu akan memberikan perhatian pada kebutuhan pribadinya, tidak sekedar berfokus pada kebutuhan atau kepentingan orang lain. Selain itu, individu yang memiliki selfcontrol akan membatasi dirinya untuk berbuat perilaku negatif karena pengendalian diri memiliki arti sebagai kemampuan individu dalam menahan dorongan atau keinginan untuk bertingkah laku negatif yang tidak sesuai dengan norma. Dengan memiliki selfcontrol, individu juga dapat memenuhi kebutuhannya secara seimbang karena ia dapat menentukan ukuran kebutuhan yang harus dipenuhi secara wajar dan tidak berlebih-lebihan.

Hasil penelitian yang dilakukan olehTeng, Li dan Liu (2014) menunjukkan adanya korelasi antara agresifitas, kecanduan internet, dangameonline, dengan kontrol diri yang rendah di kalangan siswa. Selanjutnya, penelitian yang dilakukan oleh Mehroof \& Griffith (2010) yang melibatkan 123 mahasiswa Universitas East Midlands di Inggris, menunjukkan bahwa terdapat hubungan yang signifikan antara lima sifat (neurotisisme, mencari sensasi, ciri kecemasan, kontrol diri, dan agresi) dengan kecanduan game online. Hal ini didukung oleh hasil penelitian yang dilakukan oleh Budhi \& Endang (2016) menunjukkan bahwa terdapat hubungan yang negatif antara kontrol diri dengan intensitas bermain gameonline pada mahasiswa pemain gameonline di game center X Semarang dimana nilai koefisien relasinya sebesar -0.817 dengan $\mathrm{p}=0.00(\mathrm{p}<0.01)$, artinya semakin tinggi kontrol diri maka semakin rendah intensitas bermain gameonline. Penelitian lain yang dilakukan oleh Chen dan Chang (2008) menunjukkan bahwa berdasarkan analisis korelasi kanonik, variabel estetika, karakter dan interaksi sangat berkaitan dengan aspek-aspek dalam variable kecanduan gameonline, yaitu withdrawal dan torelance. Chen dan Chang menemukan bahwa para pemain gameonline didominasi oleh laki-laki remaja dan laki-laki dewasa yang berusia diatas tiga puluh tahun.

Penjabaran mengenai penelitianpenelitian yang telah dilakukan tersebut menunjukkan bahwa penelitian sebelumnya lebih menekankan kepada selfcontrol yang dimiliki individu karena kecanduan internet dangameonlineyang terjadi pada kalangan remaja maupun orang dewasa. Sedangkan penelitian yang akan peneliti lakukan terkait selfcontrol dan intensitas bermaingameonlinepada kalangan anakanak usia sekolah. Hal ini menunjukkan bahwa penelitian yang akan dilakukan cukup berbeda dengan penelitian sebelumnya, serta menunjukkan bahwa 
penelitian yang akan dilakukan belum pernah diteliti sebelumnya.

Berdasarkan uraian diatas, maka rumusan masalah dalam penelitian ini yaitu apakah terdapat hubungan antara selfcontrol dengan intensitas bermain gameonline pada anak usia sekolah? Adapun tujuan dari dilakukannya penelitian ini adalah untuk mengetahui ada atau tidaknya hubungan antara selfcontrol dengan intensitas bermain gameonline pada anak usia sekolah. Manfaat dilakukannya penelitian ini adalah untuk memberikan informasi mengenai hubungan antara selfcontrol dengan intensitas bermain gameonline pada anak usia sekolah. Selain itu, dengan adanya penelitian ini, diharapkan individu dapat mengetahui bahwa perilaku bermaingameonline dapat menimbulkan beberapa dampak negatif bagi para pelakunya yang dapat menyebabkan kerugian serta dapat memberikan efek candu bagi para pelaku yang apabila hal tersebut terjadi, maka harus dilakukan penanganan yang serius untuk menyembuhkannya. Hipotesa penelitian ini adalah terdapat hubungan antara selfcontrol dengan intensitas bermaingameonline pada anak usia sekolah.

\section{METODE}

Penelitian ini
desain penggunakan
korelasional, dimana penelitian ini
dilakukan untuk mengetahui hubungan

dua variabel, yaitu sejauh mana variasi dalam satu variabel berhubungan dengan variabel lain. Alasan digunakannya penelitian korelasional ini bertujuan untuk mengetahui hubungan antara dua variabel, yaitu variabel selfcontrol dan intensitas bermaingameonline.

Populasi dalam penelitian ini merupakan siswa sekolah dasar (SD) kelas 4, 5, dan 6 yang berusia 10 hingga 12 tahun yang berada di SDN Branta Paseser 1, Pamekasan, Madura dengan jumlah populasi 235 orang. Dengan menggunakan tabel Isaac dan Michael (dalam Sugiyono, 2014) diketahui bahwa jumlah sampel yang diambil dengan taraf kesalahan 5\% adalah sebanyak 139 yang peneliti bulatkan menjadi 140 orang.

Pengambilan subjek dalam penelitian ini menggunakan metode probability sampling dengan teknik proportionate stratified random sampling. Menurut Sugiyono (2014) proportionate stratified random sampling digunakan apabila populasi mempunyai anggota/unsur yang tidak homogen dan berstrata secara proporsional. Alasan digunakannya metode ini adalah karena sampel yang akan diambil meliputi strata (tingkatan kelas) yaitu kelas 4, 5, dan 6. Adapun cara menentukan ukuran sampel dalam setiap strata (setiap kelas) menurut Sugiyono (2014) adalah sebagi berikut:

\section{Sampel setiap kelas $=\frac{\sum \text { anak dalam kelas }}{\sum \text { populasi }} \times \sum$ sampel dengan sig $5 \%$}

Peneliti melibatkan subjek kanakkanak akhir yang berusia 10-12 tahun ini, karena pada masa ini anak sudah dapat memahami kalimat dan menginterpretasikan kalimat-kalimat. Usia kanak-kanak akhir telah mampu memahami kalimat-kalimat abstrak, sehingga dapat memahami setiap kalimat dalam pengurukuran psikologis yang telah dilakukan. Soetjiningsih (2012) mengatakan bahwa kelancaran membaca dan pemahaman kalimat terjadi pada anak usia 11-12 tahun. Selain itu, Lever (dalam Soetjiningsih, 2012) mengatakan bahwa masa ini merupakan masa bermain anak dimana selama bermain, anak-anak mengembangkan berbagai keterampilan 
sosial untuk menikmati keanggotaan kelompok dalam masyarakat anak-anak. Selanjutnya, Santrock (2012) mengatakan bahwa games memiliki peran yang sangat kuat dalam kehidupan anak sekolah dasar. Santrock mengatakan bahwa jumlah frekuensi permainan yang paling tinggi terjadi pada anak usia 10 - 12 tahun.

Variabel bebas dalam penelitian ini adalah selfcontrol, dan variabel terikat dalam penelitian ini adalah intensitas bermaingameonline. Selfcontrol adalah kemampuan anak untuk membedakan yang benar dan salah, yang baik dan buruk serta mengatur dan mengelola perilakumereka untuk melawan godaan tertentu. Intensitas bermaingameonline adalah frekuensi dan durasi yang digunakan oleh anak-anakdalam bermain game yang digubungkan dengan koneksi internet, baik melalui handphone, tablet, maupun komputer.

Terdapat dua skala/alat ukur/instrumen yang digunakan untuk mengukur selfcontrol dan intensitas bermaingameonline dalam penelitian ini. Alat ukur yang pertama adalah alat ukur yang digunakan untuk mengukur selfcontrol, dimana skala ini diadaptasi dan dimodifikasi berdasarkan skala self control yang disusun oleh Tangney, dkk (2004) berdasarkan lima aspek, yaitu disiplin diri, tindakan nonimpulsif, kebiasaan sehat, etika dalam mengerjakan suatu pekerjaan, dan reliabilitas diri. Skala kedua yaitu untuk mengukur intensitas bermain gameonline yang dilakukan oleh anak usia sekolah yang terdiri dari dua aspek yaitu, frekuensi dan durasi. Alat ukur inidiadaptasi dan dimodifikasi dari skala intensitas bermain game online yang disusun oleh Dewandari (2013) yang digunakan untuk mengukur intensitas bermain game online pada remaja kelas $\mathrm{X}$.
Skala-skala tersebut berjumlah 36 item padaskala self controldan 30 item pada skala intensitas bermain game onlineserta merupakan skala likertdengan menggunakan format 4 pilihan jawaban yaitu Sangat Setuju (SS), Setuju (S), Tidak Setuju (TS), dan Sangat Tidak Setuju (STS).

Uji coba skala dilakukan kepada 60 responden yang berdomisili di Kota Malang, tepatnya pada siswa salah satu Sekolah Dasar yang ada di kelurahan Sumbersari, Malang. Responden dipilih berdasarkan kriteria yaitu, merupakan siswa kelas 4, 5, atau 6 yang berusia 1012 tahun. Kegiatan ini dilakukan untuk mengetahui validitas dan reliabilitas pada kedua skala penelitian. Adapun hasil analisa uji statistik dengan menggunakan Statistical Program for Social Science (SPSS) versi 21 diperoleh indeks validitas dan reliabilitas.

Berdasarkan hasil uji validitas dan reliabilitas kedua alat ukur tersebut, diketahui bahwa skala self control yang terdiri dari 36 item terdapat 27 item yang valid dan 9 item gugur dimana indeks validitas berada pada rentangan 0,310 - 0,732 dan angka reliabilitas skala diketahui berdasarkan nilai cronbach's alpha adalah 0,914. Sedangkan pada skala intensitas bermain game online diketahui terdapat 27 item yang valid dan 3 item yang gugur dengan indeks validitas berada pada rentang $0,392-0,869$ dan nilai reliabilitas berdasarkan cronbach's alpha sebesar 0,959. Validitas item diperoleh apabila nilai koefisien berkisar antara $0,30-0,50$ yang artinya telah dapat memberikan kontribusi yang baik terhadap efisiensi suatu penelitian (Cronbach, dalam Azwar 2017). Berdasarkan hal tersebut dapat diketahuipula bahwa instrumen/skala self control dan intensitas bermain game online yang digunakan dalam penelitian ini adalah reliabel karena telah memenuhi syarat, yaitu nilai cronbach's 
alpha $\geq 0,80$ atau 0,85 (Wells \& Wollack, dalam Azwar 2017).
HASIL :

Berdasar analisis deskriptif terhadap data yang dikumpulkan maka diperoleh hasil seperti pada tabel 1. Di bawah ini.

Tabel 1. Hasil Penghitungan Kategori Skala Self Control

\begin{tabular}{ccc}
\hline Kategori & Frekuensi & Persentase (\%) \\
\hline Tinggi & 77 & $55 \%$ \\
Rendah & 63 & $45 \%$ \\
Total & 140 & $100 \%$ \\
\hline
\end{tabular}

Berdasarkan tabel 1 diketahui bahwa responden dengan self control tinggi berjumlah 77 orang dengan persentase kategori tinggi sebesar 55\% dan responden dengan self control rendah berjumlah 63 orang dengan persentase kategori rendah sebesar $45 \%$. Sehingga dapat diketahui bahwa sebagian besar responden tersebut memiliki self control yang tinggi. Hal tersebut memiliki arti bahwa respondenresponden tersebut dapat mengendalikan, mengontrol, mengelola, serta mengarahkan diri mereka untuk melawan godaan-godaan tertentu seperti bermain game yang berlebihan. Sebaliknya, responden yang memiliki self control yang rendah kurang dapat menahan diri untuk mengontrol dan mengarahkan diri mereka.

Tabel 2. Penghitungan Kategori Skala Intensitas Bermain Game Online

\begin{tabular}{ccc}
\hline Kategori & Frekuensi & Persentase (\%) \\
\hline Tinggi & 76 & $54 \%$ \\
Rendah & 64 & $46 \%$ \\
Total & 140 & $100 \%$ \\
\hline
\end{tabular}

Berdasarkan tabel 2, dapat diketahui bahwa terdapat 76 responden dengan yang termasuk dalam kategori intensitas bermain game online yang tinggi dengan persentase sebesar 54\%, sedangkan untuk kategori intensitas bermain game online yang rendah terdapat 64 responden dengan persentase kategori rendah sebesar 46\%. Hal tersebut menunjukkan bahwa sebagian besar responden memiliki intensitas bermain game online tinggi, yang artinya responden memiliki jam bermain dan mengakses game online yang tinggi pula. 
Novita Febriyanti Rahayu Putri : The Relationship Between Self Control ...

Psikodimensia Vol.17/ 2, 2018 | 120-134 | DOI 10.24167/psidim.v17i2.1636

Tabel 3. Penghitungan Kategori Skala Self Control Berdasarkan Usia

\begin{tabular}{cccc}
\hline Usia & Kategori & Frekuensi & Persentase (\%) \\
\hline 10 Tahun & Tinggi & 24 & $77 \%$ \\
& Rendah & 7 & $23 \%$ \\
Total & & 31 & $100 \%$ \\
\hline 11 Tahun & Tinggi & 25 & $39 \%$ \\
& Rendah & 39 & $61 \%$ \\
Total & & 64 & $100 \%$ \\
\hline 12 Tahun & Tinggi & 28 & $62 \%$ \\
& Rendah & 17 & $38 \%$ \\
Total & & 45 & $100 \%$ \\
\hline
\end{tabular}

Pada tabel 3diketahui bahwa berdasarkan penghitungan kategori pada skala self control untuk responden yang berusia 10 tahun memiliki frekuensi sebesar 24 reponden dengan persentase kategori tinggi sebesar $77 \%$. Selanjutnya, pada usia 11 tahun responden yang memiliki self control tinggi sebanyak 25 responden dengan persentase kategori tinggi sebesar 39\%, dan pada usia 12 tahun responden memiliki self control tinggi sebanyak $28 \%$ dengan presentasi kategori tinggi sebesar $62 \%$. Hal tersebut menunjukkan bahwa bahwa sebagian besar responden memiliki self control yang tinggi dan semakin tinggi usia seseorang maka semakin tinggi pula self control yang dimiliki. Artinya, bahwa usia mempengaruhi self control yang dimiliki oleh individu. Selain itu, tabel 3 juga menjukkan bahwa responden-responden tersebut dapat mengendalikan, mengontrol, mengelola, serta mengarahkan diri mereka untuk melawan godaan-godaan tertentu seperti bermain game yang berlebihan. Sebaliknya, responden yang memiliki self control yang rendah kurang dapat menahan diri untuk mengontrol dan mengarahkan diri merek.

Tabel 4. Penghitungan Kategori Skala Intensitas Bermain Game Online Berdasarkan Usia

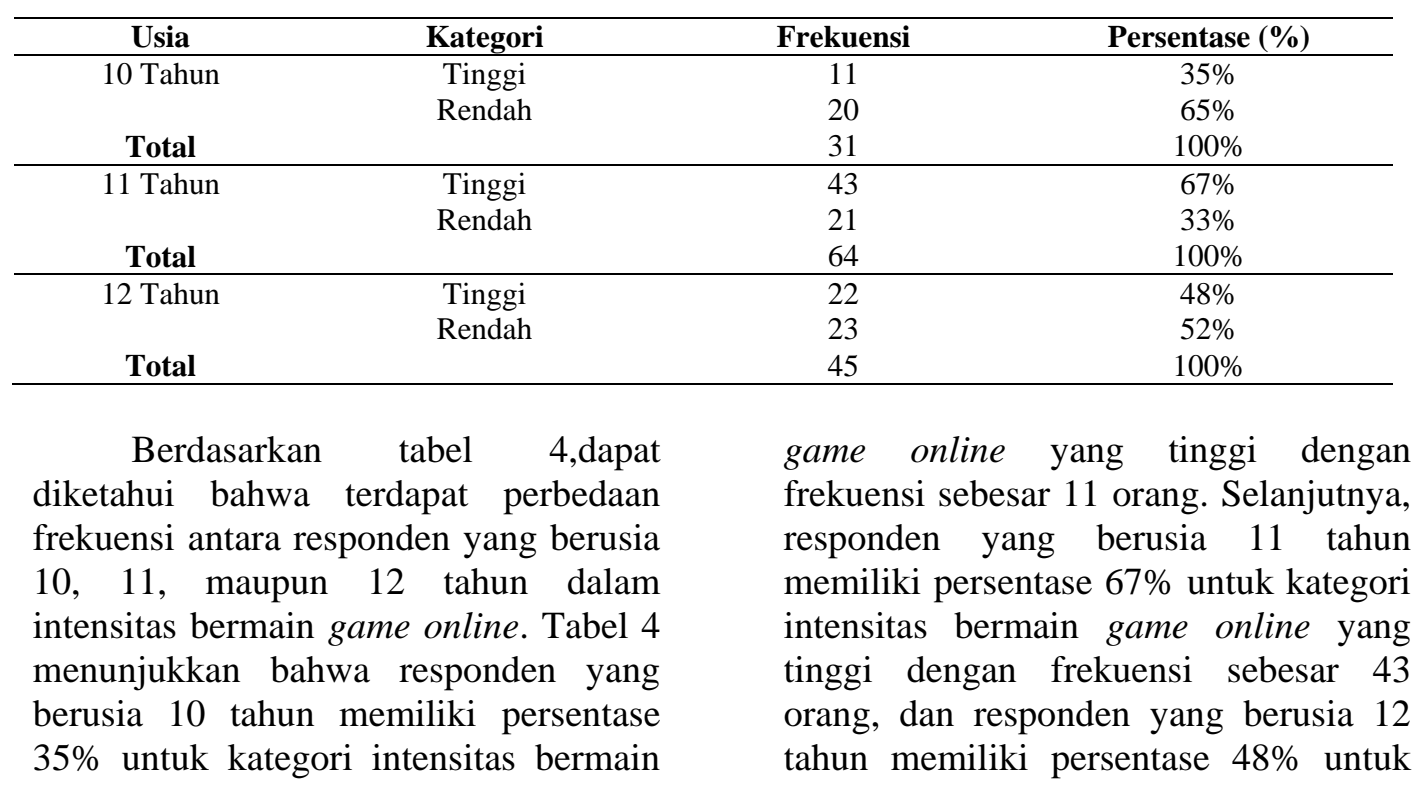


kategori intensitas bermain game online yang tinggi dengan frekuensi sebesar 22 orang. Hal ini menunjukkan bahwa responden yang berusia 11 tahun memiliki intensitas bermain game online yang tinggi jika dibandingkan dengan responden yang berusia 10 dan 12 tahun.

Hasil uji normalitas data Kolmogorov-Smirnov Test dengan menggunakan SPSS versi 21, diketahui bahwa nilai signifikansiKolmogrovSmirnov (sig. 2-tailed) sebesar 0,524 pada variable self control dan 0,254 pada variabel intensitas bermain game online. Artinya bahwa $\alpha>0,05$ (taraf kesalahan 5\%). Dikatakan data berdistribusi normal jika nilai signifikansi lebih besar dari 0,05 (sig. > $0,05)$. Melalui hasil uji kenormalan data dapat disimpulkan bahwa data yang digunakan dalam penelitian ini berdistribusi normal. Oleh karena data berdistribusi normal, maka uji korelasi menggunakan Product Moment Pearson dapat dilakukan.

Berdasarar analisis korelasi product moment, diperoleh nilai $\mathrm{r}=$ 0.804 dengan $p=0,000$. Berdasarkan hasil uji korelasi tersebut,dapat disimpulkan bahwa terdapat hubungan yang signifikan antara self controldenganintensitas bermain game onlinepada anak usia sekolah. Koefisien korelasi yang negatif menunjukkan bahwa hubungan bersifat negatif atau berlawanan arah. Hal tersebut memiliki arti bahwa semakin rendah perolehan skor self control maka semakin tinggi intensitas bermain game online. Selain itu, nilai koefisien determinasi $\left(\mathrm{r}^{2}\right)$ yang diperoleh adalah 0,646 yang menunjukkan kontribusi self controlterhadap intensitas bermain game onlinesebesar $64,6 \%$, yang artinya terdapat $35,4 \%$ faktor lain yang dapat mempengaruhi intensitas bermain game online.

\section{DISKUSI}

Hasil uji analisis data yang telah dilakukan menunjukkan bahwa hipotesis dalam penelitian ini diterima. Artinya, terdapat hubungan antaraself control dengan intensitas bermain game online pada anak usia sekolah.Adanya korelasi tersebut menunjukkan bahwa seorang anak yang memiliki self control dapat mengontrol, mengelola, ataupun mengarahkan dirinya untuk memikirkan risiko terhadap setiap aktivitas yang dilakukan sehingga ia dapat mengontrol dan membatasi diri ketika bermain game online yang membuat intensitas bermain game online-nya menjadi rendah.

Nilai koefisien korelasi (r) yang bersifat negatif menunjukkan bahwa semakin rendah perolehan skor skalaself controlmaka semakin tinggi tingkat intensitas bermain game online pada anak. Sebaliknya semakin tinggi perolehan skor pada skalaself controlmaka semakin rendah tingkat intensitas bermain game online pada anak. Berdasarkan hal tersebut dapat disimpulkan bahwa self control berhubungan dengan intensitas seorang anak dalam bermain game online. Penelitian ini menunjukkan bahwa ketika anak-anak tidak membatasi dirinya dalam bermain game online, maka muncullah faktor-faktor adiksi bermain game online, yang salah satunya adalah faktor internal atau faktor yang muncul dari dalam diri individu itu sendiri. Faktor-faktor internal tersebut salah satunya adalah rendahnya self control yang dimiliki anak-anak sehingga mereka kurang mampu dalam mengantisipasi dampak negatif yang timbul akibat dari bermain game online yang berlebihan (Masya dan Candra, 2016). Ketika anak telah memiliki intensitas bermain gameonline yang tinggi, maka mereka cenderung akan melalaikan tugas utama mereka, yaitu belajar.

Selain itu, tingginya intensitas bermain game online pada anak akan 
mengakibatkan beberapa dampak negatif, seperti terganggunya kesehatan fisik anak karena pola makan anak terganggu akibat game online, paparan cahaya dari komputer ataupun gadget yang dapat merusak saraf mata dan otak pada anak (Young 2009; Nuhan 2016). Dampak lain dari tingginya intensitas bermain game online pada anak adalah dampak psikis yang mengakibatkan anak kurang dapat berkonsentrasi dalam belajar, melalaikan tugas-tugas yang diberikan guru, bisa berbohong, membolos sekolah demi dapat bermain game online, serta menjadi kurang peduli terhadap lingkungan sekitar karena yang dipikirkan hanyalah game online.

Hasil penelitian ini sejalan dengan penelitian sebelumnya yang dilakukan oleh Ismail \& Zahraweh (2017) pada 284 mahasiswa di Universitas Najran, Saudi Arabia yang menunjukkan bahwa terdapat hubungan antara self control dan adiksi mahasiswa terhadap internet, dimana semakin rendah self control mahasiswa maka semakin tinggi tingkat kecanduan mereka terhadap internet. Begitupun sebaliknya, semakin tinggi tingkat self control mahasiswa, maka semakin rendah tingkat kecanduan mereka terhadap internet. Selain itu, hasil penelitian yang dilakukan oleh Budhi \& Endang (2016) menunjukkan bahwa terdapat hubungan yang negatif antara kontrol diri dengan intensitas bermain gameonline pada mahasiswa pemain gameonline di game center $\mathrm{X}$ Semarang dimana nilai koefisien relasinya sebesar -0.817 dengan $p=0.00$ $(\mathrm{p}<0.01)$, artinya semakin tinggi kontrol diri maka semakin rendah intensitas bermain gameonline.

Self control memiliki peranan penting dalam setiap tindakan yang dilakukan individu. Dalam penelitian ini dibuktikan bahwa ketika anak memiliki self control yang tinggi, maka ia dapat mengurangi

perilaku-perilaku maladaptif serta memiliki kesadaran untuk memilih hal-hal dan perilaku yang positif, seperti tidak memiliki intensitas yang tinggi dalam bermain game online.Individu dengan self control tinggi dapat memiliki nilai dan prinsip yang sesuai dengan norma-norma sosial, dan self control yang tinggi dapat membantu individu untuk menyadari setiap perilaku yang ia lakukan serta dapat merubah respon yang akan dimunculkan (Tangney \& Baumeister 2004). Artinya, self control yang tinggi dapat mengontrol setiap perilaku anak serta dapat mengarahkan perilakuperilaku tersebut menjadi perilaku yang positif. Penelitian yang dilakukan oleh Ningtyas (2012) menunjukkan bahwa self control yang dimiliki oleh individu membuat mereka mampu mengontrol dan mengendalikan perilaku, serta dapat mengambil keputusan atau suatu tindakan yang cukup baik terhadap dirinya. Hal tersebut menunjukkan bahwa self control dapat mendorong perilaku seseorang menjadi positif.

Penelitian ini juga menunjukkan bahwa anak yang memiliki self control yang rendah memiliki kecenderungan lebih besar untuk menentukan tingginya tingkat intensitas anak-anak tersebut dalam bermain game online. Hal ini sejalan dengan penelitian yang dilakukan oleh Mehroof dan Griffiths (2010), yang menunjukkan bahwa para pemain game mengorbankan aktivitas yang lain untuk bisa bermain game, para gamers tersebut mengorbankan waktu untuk melakukan kebiasaan yang lain, mereka rela mengorbankan waktu untuk tidur, waktu bekerja maupun waktu belajar mereka demi dapat bermain game.

Young (2009), mengatakan bahwa bermain game online dapat mengakibatkan kecanduan, dimana seseorang yang mengalami kecanduan akan menghabiskan waktu berjam-jam bahkan berhari-hari hanya untuk 
bermain game online. Piyeke (dalam Budhi dan Endang, 2016) menyimpulkan bahwa penyebab seseorang bermain game online secara berlebihan dikarenakan oleh rutinitas yang membosankan, kurangnya kesempatan untuk bersantai dari padatnya jadwal sekolah atau kuliah, suasana tempat tinggal yang jauh dari kenyamanan yang menyebabkan seseorang betah berlama-lama di game centeratau warung internet (warnet), serta adanya ajakan teman dalam bermain game untuk tetap sama-sama memainkan game online.

Rendahnya self control pada anak dalam penelitian ini menunjukkan bahwa mereka kurang dapat mengarahkan perilaku mereka sehingga berdampak pada tingginya intensitas anak dalam bermain game online. Penelitian ini sejalan dengan penelitian yang dilakukan oleh Budhi \& Endang (2016) yang mengatakan bahwa rendahnya kontrol diri yang dimiliki oleh seseorang dikarenakan orang tersebut tidak memiliki kemampuan dalam menggunakan behavioral control,cognitive control, dan decisional control.

Ghufron dan Risnawita (2010) menjelaskan bahwa behavioral control meliputi kemampuan mengontrol keinginan dalam diri, kemampuan mengendalikan situasi diluar diri individuserta tidak mampu memahami berbagai stimulus, cognitive control meliputi kemampuan menilai suatu keadaan lingkungan dengan baik, serta kemampuan mengantisipasi stimulus yang tidak diharapkan. Selanjutnya decisional control meliputi kemampuan mengambil tindakan atas permasalahan yang dihadapi, serta kemampuan mempertimbangkan berbagai sisi sebelum melakukan suatu tindakan. Ningtyas (2012) menyimpulkan berdasarkan penelitian yang telah dilakukannya bahwa self control yang rendah mengindikasikan bahwa seseorang kurang mampu dalam mengendalikan emosi serta dorongandorongan dari dalam dirinya, individu kurang mampu mengontrol perilaku dalam bermain hal-hal yang menyenangkan dirinya sehingga membuat individu bermain secara berlebihan, serta kurangnya kemampuan individu dalam dalam mengambil keputusan atas suatu tindakan yang dilakukannya.

Selanjutnya hasil penelitian ini juga menunjukkan bahwa self control memiliki sumbangan efektif atau memiliki kontribusi sebesar $64,6 \%$ terhadap intensitas anak usia sekolah dalam bermain game online. Hasil tersebut menunjukkan bahwa terdapat $35,4 \%$ faktor lain yang dapat mempengaruhi intensitas individu dalam bermain game online. Chen dan Chang (2008) mengatakan bahwa faktor lain yang mempengaruhi intensitas dan adiksi individu dalam bermain game online adalah faktor gender atau jenis kelamin. Hasil penelitian yang dilakukan oleh Chen dan Chang (2008) pada 1674 subjek di National Taiwan University's menunjukkan bahwa para pemain game online didominasi oleh laki-laki remaja dan laki-laki dewasa yang berusia diatas tiga puluh tahun.

Penelitian lain menunjukkan bahwa tingginya tingkat kecanduan individu pada game online dipengaruhi oleh kepribadian yang dimiliki. Hasil penelitian yang dilakukan oleh Kim, Namkoong, dan $\mathrm{Ku}$ (2008) menunjukkan bahwa agresi dan sifat narsistik kepribadian berkorelasi positif dengan kecanduan game online, sedangnkan kontrol diri berkorelasi negatif dengan kecanduan game online ( $\mathrm{p}<0,001)$.Selain itu, pada penelitian tersebut juga menunjukkan bahwa analisis regresi berganda menunjukkan bahwa tingkat kecanduan game dapat diprediksi berdasarkan sifat kepribadian 
narsistik seseorang, agresi, kontrol diri, hubungan dengan orang lain, dan pekerjaan. Faktor-faktor tersebut dapat menjadi faktor-faktor tambahan individu atau faktor yang berkontribusi dalam tingginya tingkat intensitas individu dalam bermain game online.

\section{SIMPULAN}

Berdasarkan penelitian yang telah dilakukan, dapat disimpulkan bahwa hipotesis dalam penelitian ini diterima. Artinya terdapat hubungan antara self control dengan intensitas bermain game online pada anak usia sekolah, dimana terdapat hubungan negatif dan signifikan antara kedua variabel tersebut. Hasil tersebut dapat diartikan bahwa semakin tinggi self control anak-anak maka semakin rendah intensitas bermain game online mereka. Serta sebaliknya semakin rendah self control yang anak-anak miliki maka semakin tinggi tingkat intensitas bermain game online pada anak-anak.

Implikasi dari penelitian ini adalah bagi anak-anak usia kanak-kanak akhir yang memiliki intensitas bermain game online yang tinggi dan self control yang rendah agar dapat mengontrol dan meningkatkan self control sehingga produktivitas meningkat dan dapat mengurangi intensitas dalam bermain game online karena tugas utamanya adalah belajar. Individu yang memiliki self control yang tinggi maka ia akan cenderung memikirkan segala risiko atas segala tindakan yang dilakukan serta tidak melakukan segala sesuatu dengan berlebih-lebihan. Bagi orang tua, agar memantau setiap aktivitas yang dilakukan oleh putra/putrinya serta memberikan pengetahuan tentang dampak buruk dan akibat dari tingginya intensitas bermain game online, mengajarkan mengenai pentingnya self regulation. Oleh karena itu, mengajarkan self control pada anak sejak dini merupakan bekal yang sangat penting untuk anak ketika memasuki masa perkembangan yang selanjutnya.

Selanjutnya, implikasi bagi
fakultas agar pada kegiatan pengembangan mahasiswa untuk menambahkan kajian mengenai hal-hal yang berkaitan dengan self control maupun game online, baik cara mengembangkan self control sesuai usia anak maupun risiko dan dampak dari adiksi bermain game onlinebagi anakanak sehingga dapat memberikan edukasi bagi mahasiswa. Selain itu, peran fakultas juga dapat membekali orang tua cara mengembangkanself control pada anak sesuai dengan usia anak dan memberikan keterampilan pada orang tua ketika anak telah terindikasi kecanduan game online, misalnya dengan melalui mata kuliah aplikasi psikologi dalam keluarga.

Bagi peneliti selanjutnya disarankan untuk melakukan penelitian terkait self control dan intensitas bermain game onlinepada individu khususnya anak-anak dengan mencantumkan pola asuh maupun peran orang tua pada instrumen penelitian yang digunakan, misalnya responden tinggal bersama kedua orang tua atau tidak.

Peneliti selanjutnya juga dapat melibatkan responden dengan usia dan jenis kelamin subjek dengan jumlah yang sama sehingga dapat terlihat perbedaan maupun persamaan yang signifikan dari jumlah subjek yang sama. Selain itu, peneliti selanjutnya dapat melakukan penelitian terkait adiksi bermain game online pada anak yang dipengaruhi oleh faktor lain selain self control. Peneliti selanjutnya juga dapat melakukan intervensi pada anakanak yang telah terindikasi kecanduan game online agar dapat mengurangi atau bahkan menghilangkan kecanduan yang dirasakan. Peneliti selanjutnya juga dapat memperkaya subjek penelitian 
dengan menambah jumlah subjek dan tidak hanya sebatas pada satu sekolah seperti pada penelitian ini.

\section{DAFTAR PUSTAKA}

Asosiasi Penyelenggara Jasa Internet Indonesia. (2015). Profil Pengguna Internet Indonesia 2014. Jakarta: Pusat Kajian Komunikasi Universitas Indonesia.

Azwar, S. (2017). Penyusunan skala psikologi, Edisi 2. Yogyakarta: Pustaka Pelajar.

Budhi, F. H.,\& Endang, S., I. (2016). Hubungan antara kontrol diri dengan intensitas bermain game online pada mahasiswa pemain game online di game centre $\mathrm{X}$ semarang. Jurnal Empati. 5, (3). Agustus 2016. 478 - 481.

Chen, C. Y., \& Chang, S. L. (2008). An exploration of the tendency to online game addiction due to user's liking of design features. Asian Journal of Health and Information Sciences. 03, (1-4), pp. 38-51, 2008.

Dewandari, S. (2013). Hubungan antara intensitas bermain game online dengan motivasi belajar siswa kelas X SMK Negeri 1 Sarupan Kabupaten Wonosobo. Skripsi, Fakultas Keguruan dan Ilmu Pendidikan, Universitas Kristen Satya Wacana.

Ghufron, M. N., \& Risnawita, R. S. (2010). Teori-teori psikologi. Jogjakarta: Ar-ruzz Media.

Herudin. (2014, January 31th). http://www.tribunnews.com/iptek/ 2014/01/31/ada-25-juta-orangindonesia-doyan-main-gameonline. (diakses pada tanggal 6 Januari 2018).
Hurlock, E. B. (2008). Perkembangan anak jilid 2. Jakarta: Erlangga.

Ismail, A.B., \& Zawahreh, N. (2017). Self controland its relationship with the internet addiction among a sample of Najran University Students.Journal of Education and Human Development. 06, (02). $186-174$.

Kim, E. J., Ku,T., dan Namkoong, S. J. (2008). The relationship between online game addiction and aggression, self control and narcissistic personality traits. European Psychiatry. 23, (212 218).

Lemmens, J. S., dkk. (2009). Development and validation of a game addiction scale for adolescents. Media Psychology. The Amsterdam School of Communication Research (ASCoR), University of Amsterdam, Amsterdam, The Netherlands. Version of Record first Publish: 5 Maret 2009.

Masya, H., \& Candra, D.A. (2016). Faktor-faktor yang mempengaruhi perilaku gangguan kecanduan game online pada peserta didik kelas $\mathrm{X}$ madrasah aliyah $\mathrm{Al}$ Furqon Prabumulih tahun pelajaran 2015/2016. Jurnal Bimbingan dan Konseling, 03, (1) , 153-169.

Maulana, R. (2017, February 27th). https://id.techinasia.com/perkemb angan-pasar-game-indonesiasalah-satu-yang-tertinggi-di2016.(diakses pada tanggal 7 Januari 2018).

Meggit, C. (2013). Memahami perkembangan anak. Jakarta: PT Indeks.

Mehroof, M., \& Griffith, M, D. (2010). Online gaming addiction: The role of sensation seeking, Self control, 
Neuroticism, Aggression, State anxiety, And trait anxiety. Journal Cyberpsychology, Behavior, and Social Networking. 13, (3), 2010.

Ningtyas, S. D. Y. (2012). Hubungan antara self control dengan internet addiction pada mahasiswa. Eductional Psychology Journal. EJP 1, (1), (2012).

Nuhan, M. Y. G. (2016). Hubungan intensitas bermain game onlinedengan prestasi belajar siswa kelas IV sekolah dasar negeri Jarakan Kabupaten Bantul Yogyakarta. Jurnal Pendidikan Guru Sekolah Dasar, Edisi 6 Tahun ke-5, 2016.

Pertiwi, I. (2016, October 27th). https://www.rappler.com/Indonesi a/ berita/ 150478-penggunainternet-indonesia. (diakses pada tanggal 5 Februari 2016).

Santrock, J.W. (2012). Life span development. Jakarta: Erlangga.

Soetjiningsih, C. H. (2012). Perkembangan anak sejak pertumbuhan sampai dengan kanak-kanak akhir. Jakarta: Prenada Media group

Sugiyono. (2014). Statistika untuk penelitian. Bandung: Alfabeta.

Tangney, J. P., Roy, F. B., \& Angie, L. B. (2004). High self-control predicts good adjustment, Less pathology, Better grades, And interpersonal success. Journal of Personality. 72, (2).

Teng, Z., Yujie, L., \& Yanling, L. (2014). Onlinegaming, internet addiction, And aggression of Chinese male sudents: The mediating role of low self-control. International Journal of Psychological Studies. 6, (2).

Ursia, N.R., Ide, B.S., \& Nadia, S. (2013). Prokrastinasi akademik dan self-control pada mahasiswa skripsi Fakultas Psikologi Universitas Surabaya. Makara Seri Sosial Humaiora. 17, (1), 1 18.

Young, K. S. (2009). Understanding onlinegaming addiction and treatment issues for adolescents. The American Journal of Family Therapy. $355-372$.

Zulkarnain. (2002). Hubungan kontrol diri dengan kreativitas pekerja. USU Digilib: Universitas Sumatera Utara. 